\title{
Nilai-Nilai Pendidikan Dalam Tari Sanghyang Manik Geni Di Pura Serayu Desa Adat Canggu, Kuta Utara-Badung
}

\author{
Ni Wayan Karmini ${ }^{1}$, Wayan Paramartha ${ }^{2}$
}

Pascasarjana Program Studi Pendidikan Agama Hindu, Universitas Hindu Indonesia, Denpasar

karmini.niwayan@yahoo.com

\begin{abstract}
Walaupun masyarakat Desa Canggu tengah digempur dengan nilai-nilai kehidupan modern yang menyertai aktifitas kehidupan kapariwisataan, tradisi seni-budaya masyarakat setempat masih tetap eksis, termasuk keberadaan Tari Sanghyang Manik Geni. Karya ilmiah ini sengaja membahas proses dan fungsi tari Sanghyang Manik Geni dalam upacara piodalan di Pura Serayu Desa Adat Canggu, serta nilai-nilai kependidikan yang terkandung di dalamnya. Makalah ini merupakan hasil penelitian kualitatif yang datanya dikumpualkan melalui observasi, studi dokumentasi dan wawancara mendalam dengan 10 informan, yaitu pelaku tari Sanghyang Manik Geni, pemuka adat serta pemerhati seni-budaya Bali yang ditentukan secara snow ball sampling. Analisis data dilakukan secara kualitatif deskriptif dengan menerapkan beberapa teori secara eklektis, yaitu teori religi, teori estetika serta teori fungsional struktural. Hasil kajian menunjukkan bahwa pementasan tari Sanghyang Manik Geni yang diiringi oleh gamelan gong gede merupakan tari wali, dipentaskan di setiap piodalan di pura Serayu desa Canggu.. Tari sakral yang dipentaskan setiap buda manis dukut ini merupakan bagian dari prosesi upacara dewa yadnya dalam menunjukan rasa bakti kepada Ida Sang Hyang Widhi Wasa. Penari Sanghyang Manik Geni memakai kain putih, baju putih, dan selendang yang berwarna putih, serta memakai alat upakara berupa canang dan teteken. Tari Sanghyang Manik Geni memiliki beberapa fungsi: (a) fungsi ritual sebagai bagian dari upcara dewa yadnya, (b) fungsi sosial, yakni menguatkan rasa kebersamaan dan solidaritas masyarakat adar Desa Canggu, serta (c) fungsi ekologis yakni ikut memperkuat kesadaran masyarakat setempat dalam menjaga keseimbangan dan kelestarian lingkungan hidup. Disamping mengandung nilai estetis yang tinggi, nilai sosial religius, persembahan tari Sanghyang Manik Geni di Pura Serayu, Desa Canggu juga mengandung nilai kependidikan, yakni rasa bhakti penuh keihklasan kepada Hyang Widi Wasa, pendidikan tentang pentingnya menjaga keseimbangan dan pelestarian lingkungan hidup dan pendidikan tentang pentingnya upaya sosialisasi dan enkulturasi (pembudayaan) nilai-nilai ajaran agama Hindu kepada generasi penerus.
\end{abstract}

Kata kunci: Tari Sanghyang Manik Geni, keseimbangan sosial-ekologis, sosialisasi nilai-nilai ajaran agama Hindu.

\section{The Values Of Education In The Sang Hyang Manik Geni Dance In The Serayu Rample Of The Traditional Village Canggu, North Kuta, Badung}

Even though the community of Canggu Village was being attacked with the values of modern life that accompany tourism life activities, the tradition of local art and culture still exists, including the existence of Sanghyang Manik Geni Dance. This scientific paper deliberately discusses the process and function of the Sanghyang Manik Geni dance in the piodalan ceremony in Pura Serayu, Canggu Traditional Village, and the educational values contained therein. This paper was the result of qualitative research. Data collection was done through observation, documentation studies and in-depth interviews with 10 informants, namely with a sutri who danced the Sanghyang Manik Geni dance, as well as with local Hindu religious leaders and observers of Balinese arts and culture determined by snow ball sampling. Data analysis was carried out qualitatively descriptive by applying several theories eclectically, namely religious theory, aesthetic theory and structural functional theory. The results showed that the performance of Sanghyang dance Manik Geni accompanied by gamelan gong gede was a guardian (wali) dance, performed on every piodalan in the temple Serayu village Canggu. The sacred dance performed by each of the dukut sweet people is part of the ceremony of the god yadnya in showing devotion to Ida Sang Hyang Widhi Wasa. Sanghyang dancers Manik Geni wear white cloth, white clothes, and white scarves, and use upakara tools in the form of canang and teteken. Sanghyang Manik Geni dance has several functions: (a) ritual function as part of the god's way of yadnya, (b) social functions, namely strengthening the sense of togetherness and 
solidarity of the adar people of Canggu Village, and (c) ecological functions which help strengthen local community awareness maintain the balance and preservation of the environment. Besides containing high aesthetic values, religious social values, offerings of Sanghyang Manik Geni dance in Pura Serayu, Canggu Village also contain educational values, namely full dedication to Hyang Widi Wasa, education about the importance of maintaining balance and preservation of the environment and education about the importance efforts to socialize and enculturate (acculturate) the teachings of Hindu values to the next generation.

Keywords: Sanghyang Manik Geni dance, social-ecological balance, socialization of Hindu values.

Proses Review : 1 - 20 Agustus 2019, Dinyatakan Lolos: 22 Agustus 2019

\section{PENDAHULUAN}

Sebagaimana yang digariskan dalam Peraturan Daerah Provinsi Bali No 2 tahun 2012, orientasi pembangunan pariwisata di Bali adalah pariwisata budaya, yakni pariwisata yang bertumpu pada kebudayaan Bali (yang dijiwai oleh Agama Hindu) sebagai bagian kebudayaan nasional yang berdasarkan Pancasila. Setiap langkah dan gerak dalam kerangka pengembangan pariwisata secara normatif diharapkan tetap bertumpu pada kebudayaan Bali.

Pariwisata Bali yang berkembang sejak tahun 1920-an, telah memikat para wisatawan, termasuk wisatawan asing. Bali mampu menyedot perhatian wisatawan, karena Bali memiliki 8 faktor daya tarik sebagai destinasi wisata pilihan, yaitu: (1) harga-harga produk wisata yang wajar, (2) budaya dalam berbagai bentuk manifestasinya, (3) pantai dengan segala daya tariknya, (4) kenyamanan berwisata, (5) kesempatan luas untuk relaksasi, (6) citra (image) atau nama besar Bali, (7) keindahan alam, (8) keramahan penduduk setempat (Suradnya. 2006).

Pariwisata budaya Bali ditopang oleh potensi budaya yang menonjolkan ekspresi seni, baik karena hasil kreativitas kolektif maupun ciptaan individual. Gairah kegiatan kesenian telah menjadi bagian dari kehidupan masyarakat Bali, karena kesenian Bali merupakan bagian asal tak terpisahkan dengan aktivitas ritual keagamaan masyarakat Hindu Bali. Terbukti pada setiap kegiatan upacara khususnya piodalan, ada saja kesenian yang dipentaskan, terutama seni tari dan tabuh apalagi bagi mereka yang mampu secara material tentu akan menanggap seolah suatu kesenian dengan upacara yang diselenggarakan. Penanggapan kesenian sangat ditentukan oleh manfaat dan fungsinya dalam upacara, termasuk upacara Panca Yadnya. Secara umum, seni tari Bali dapat diklasifikasi menjadi dua jenis, yaitu tari sakral dan tari profan. Tari sakral berfungsi sebagai media yang terkonseptual di dalam rangkaian upacara. Artinya, tarian sakral merupakan suatu bentuk estetis sebagai perantara bakti yang berperan secara langsung terhadap pelaksanaan upacara. Mengingat tidak semua bentuk tarian dikategorikan ke dalam fungsinya, apalagi tari da- lam fungsi wali, bebali, dan balih-balihan. Secara detail akan dipaparkan fungsi tari, diantaranya Tari Wali adalah bentuk kesenian tari yang harus ada dalam pelaksanaan upacara (yadnya). Salah satu tari wali yang masih dipertahankan sebagai bagian dari prosesi upacara dewa yadnya adalah Tari Sanghyang Manik Geni di Pura Serayu Desa Adat Canggu, Kecamatan Kuta Utara, Kabupaten Badung. Desa Canggu telah menjadi salah satu tujuan wisata di Bali yang dikunjungi wisatawan nusantara dan mancanegara. Daya tarik Desa Canggu yang berada di wilayah Kecamatan Kuta utara ini bukan hanya pada objek wisata yang berupa keindahan alamnya, tetapi juga tradisi budaya masyarakat desa setempat yang unik. Upaya pelestarian lingkungan hidup di Desa Canggu sesuai dengan prinsip-prinsip pembangunan pariwisata berkelanjutan, yakni pembangunan obyek dan daya tarik wisata dilakukan dengan memperhatikan: (a). Kemampuan untuk mendorong peningkatan perkembangan kehidupan ekonomi dan sosial bangsa ; (b). Nilai-nilai agama, adat istiadat, serta pandangan dan nilai-nilai yang hidup dimasyarakat; (c). Kelestarian budaya dan mutu lingkungan hidup; (d). Kelangsungan usaha pariwisata itu sendiri (UU No. 9/1990, Pasal 6).

Sebagai salah satu desa tujuan wisata, pengaruh budaya modern telah merasuk ke berbagai segi kehidupan masyarakat desa setempat. Masyarakat Desa Canggu tengah digempur dengan nilai-nilai kehidupan modern yang menyertai aktifitas kehidupan kapariwisataan. Prinsip individualisme, rasionalisme dan materialism adalah beberapa nilai yang cenderung semakin menguat mewarnai tata kehidupan masyarakat desa Canggu. Walaupun telah menjalani kehidupan modern, tradisi, seni budaya masyarakat setempat masih dipegang teguh. Diantaranya adalah masih hidupnya tarian Sang Hyang Manik Geni. Tarian Sang Hyang Manik Geni ini biasanya muncul menjelang akhir prosesi piodalan, yaitu pada saat ngewisnunan di utama mandala pura Serayu tersebut. Prosesi tarian ini tiba-tiba muncul dan ditarikan oleh salah satu Sutri yang turut dalam prosesi upacara tersebut. Seorang sutri yang menarikan tarian Sang Hyang Manik Geni ini menggunakan sesenden yang berisi bara api atau teteken yang ditaruh 
di atas kepalanya sambil menari dan mengisap beberapa batang rokok. Hal itulah bedanya dari tarian Sanghyang lainnya. Tarian Sang Hyang Manik Geni berfungsi sebagai pelengkap upacara sehingga sangat berfungsi sebagai tarian wali/upacara.

Mengingat tarian ini sangat langka, yang artinya hanya muncul pada saat prosesi upacara Dewa Yadnya pada piodalan di Pura Serayu, maka sangat penting untuk diteliti dijadikan sebuah karya ilmiah dengan maksud melestarikan, sekaligus memperkenalkan eksistensi Tari Sang Hyang Manik Geni dalam upacara piodalan di Pura Serayu Desa Adat Canggu, Kabupaten Badung. Sebagai sebuah karya ilmiah, permasalahan yang dibahas adalah: (1) Bagaimanakah prosesi pementasan tari Sanghyang Manik Geni dalam upacara piodalan di Pura Serayu Desa Adat Canggu?, (2) Apakah fungsi Tari Sang Hyang Manik Geni bagi masyarakat Hindu di Desa Adat Canggu?, Nilai-nilai kependidikan apakah yang terkandung dalam Tari Sanghyang Manik Geni tersebut?.

\section{METODE PENELITIAN}

Karya ilmiah ini merupakan hasil penelitian seni-budaya, khususnya tari Sanghyang Manik Geni di Pura Serayu Desa Adat Canggu, Kecamatan Kuta Utara, Kabupaten Badung. Data penelitian diperoleh melalui: (a) studi dokumentasi yakni dokumen (bahan bacaan) atau data tertulis yang juga berupa foto-foto pada saat upacara piodalan di pura Serayu, yang berlangsungnya tari Sanghyang Manik Geni; (b) pengamatan langsung di lapangan, ketika prosesi tari Sanghyang Manik Geni sebagai bagian dari acara piodalan di di Pura Serayu Desa Adat Canggu, serta (c) wawancara mendalam dengan 10 informan, yakni dengan seorang sutri yang menarikan tarian Sanghyang Manik Geni, serta dengan pemuka agama Hindu setempat dan pemerhati seni-budaya Bali yang ditentukan secara snow ball sampling. Analisis data dilakukan secara kualitatif deskriptif dengan menerapkan beberapa teori secara eklektis, yaitu teori religi, teori estetika serta teori fungsional struktural.

\section{HASIL PENELITIAN DAN PEMBAHASAN}

Seni tari adalah bahasa gerak dimana seseorang seniman atau seniawati menyatakan ekspresi dari jiwanya melalui gerak-gerik dari sendi-sendi badannya yang dikuasai oleh irama, waktu dan pembagian ruang, waktu. Si penari dapat mencurahkan isi jiwanya dan berbicara melalui bahasa gerak serta dialog kepada penonton. Setiap etnis memiliki seni tari, termasuk masyarakat Hindu Bali. Menurut Dibia (1979), tari Bali adalah ekspresi seni dari masyarakat, yang didalamnya terkandung nilai-nilai budaya Bali.

Perkembangan tari Bali memiliki corak yang khas, diwarnai dan dijiwai oleh nilai-nilai budaya masyarakat Bali. Tari Bali merupakan kegiatan penting dari kehidupan masyarakat Bali yang sudah diwarisi sejak zaman dulu. Dan bentuk-bentuk kesenian itu sudah terpelihara sampai sekarang yang mana kehidupannya didukung oleh Agama Hindu. Tari Bali merupakan bagian organik dari masyarakat pendukungnya. Perwatakan masyarakat Bai antara lain tercermin dalam tari (Bandem, 1983:1)

Keberadaan seni tari Bali dapat dibagi menjadi 3 (tiga) periode. Pertama, periode masyarakat primitif (Pra-Hindu) yang dipengaruhi oleh keadaan alam sekitarnya. Ritme alam mempengaruhi ritme kehidupan mereka. Kedua, periode masyarakat feodal (400 M-1945) pada masyarakat feodal perkembangan tari Bali ditandai oleh elemen kebudayaan Hindu. Pengaruh Hindu di Bali berjalan sangat pelan-pelan. Dimulai pada abad VII yaitu pada pemerintahan Raja Ugra Sena di Bali. Ketiga, periode masyarakat modern (sejak tahun 1945) didalam masyarakat modern yang dimulai sejak kemerdekaan Republik Indonesia pada tahun 1945, patromisasi dari kerajaan-kerajaan di zaman feodal mulai berkurang. Secara etimologis, Manik Geni berasal dari du akata, yakni manik adalah nama dari Ida Bhetara yang berada di Pura Serayu tersebut, sedangkan Geni adalah api. Sanghyang Manik Geni adalah sebuah tarian yang di sakralkan, karena tidak sembarangan sutri dapat menarikan tarian Sanghyang ini.

Tarian Sanghyang Manik Geni ini sering muncul dalam sebuah prosesi upacara dewa yadnya atau piodalan di pura Serayu Desa Adat Canggu, Kecamatan Kuta Utara, Kabupaten Badung. Tarian ini biasanya di tarikan oleh salah seorang pemangku wanita (sutri) yang sudah mengalami kerawuhan (Trance). Beliau menarikan tarian Sanghyang ini menggunakan sesenden yang berisi bara api atau pengasepan yang ditaruh di atas kepalanya sambil menari dan mengisap beberapa batang rokok. Tarian Sang Hyang Manik Geni ini berfungsi sebagai pelengkap upacara yang bertujuan untuk turunnya para dewa-dewi pada waktu berlangsungnya upacara tersebut, tarian ini biasanya muncul menjelang akhir dari pada prosesi piodalan yaitu pada saat ngewisnunan di utama mandala daripada pura bersangkutan. Upacara piodalan merupakan bagian dari pelaksanaan Dewa Yadnya dan merupakan salah satu pengamalan dari ajaran bhakti marga. Dari segi sifatnya melaksanakan upacara piodalan merupakan tingkatan bhakti yang disebut apara bhakti atau bhakti tingkat permulaan (Cudamani, 1987:45).

Pementasan tari Sanghyang Manik Geni berlansgung dalam kegiatan upacara piodalan di pura Serayu Desa Adat Canggu Kecamatan Kuta Utara, Kabupaten Badung setiap buda manis dukut. Kegiatan upacara yang berlangsung di pura Serayu melibatkan masyarakat pendukung, teruatama masyarakat pengempon dari pura bersangkutan yang menyaksikan proses berjalannya sebuah upacara piodalan. Kegiatan kesenian yang dipentaskan pada upacara piodalan ini pada saat Ida Betara akan kembali ke alamnya (ngewisnunan), banyaknya dari pemangku/sutri yang mengalami kerawuhan. Dalam kegiatan ini, dia pentaskan beber- 


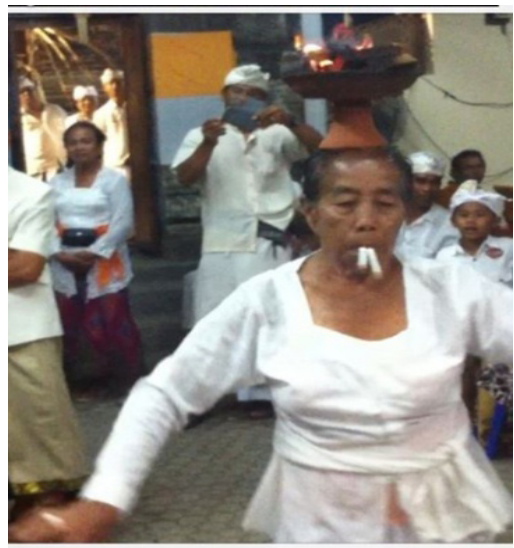

Gambar 1. Tari Sanghyang Manik Geni (Dok: AA Ngr Oka 2015)

apa tarian yang diminta oleh pemangku/sutri seperti tarian topeng sidakarya, tarian dayung sampan (tari nelayan), tarian rejang dewa, dan tarian Sanghyang Manik Geni ini. Semua pelaksanaan upacara dan kesenian ini dipercayai oleh masyarakat pengempon dari pura yang bersangkutan, untuk menunjukan rasa bakti kepada Ida Sang Hyang Widhi Wasa.

\section{Prosesi Tarian Sanghyang Manik Geni}

Tari Sanghyang Manik Geni dipentaskan melalui beberapa tahap. Pertama, tahap persiapan. Sebelum tari Sanghyang Manik Geni dipentaskan di bagian utama mandala pura Serayu desa Canggu, sang penari (sutri/pemangku) sebelum datang ke pura tersebut, diwajibkan mempersiapkan diri di rumah dengan membersihkan diri (mandi) secara skala dan meminta izin secara niskala. Ia di berikan canang pengulem yang dihaturkan ke pemerajannya masing-masing sebagai simbol meminta izin untuk undangan upacara dewa yadnya. Setelah itu. Sang penari (seorang sutra) berangkat ke pura. Ia merasa percaya diri atas izin yang sudah diperoleh untuk ngayah mesolah kepada sesuhunan. Umat Hindu yang mengikuti upacara diharapkan bertindak seperti seorang sutri ini. Mereka, sebelum datang ke pura untuk sembahyang sebaiknya juga membersihkan diri (mandi), mempersiapkan diri sebaik mungkin sehingga pada waktu persembahyangan akan terasa aman, nyaman sehingga tercipta suasana yang tenang dalam bersujud dan berbakti ke hadapan Ida Betara demi memperoleh keselamatan dan kesejahteraan.

Kedua, pementasaan inti Tarian Sanghyang Manik Geni merupakan suatu tradisi yang dilakukan setiap pelaksanaan upacara Dewa Yadnya di Pura Serayu, desa Canggu. Selama ini masyarakat Desa Canggu merasa bahwa pelksanaan upacara dewa yadnya kurang lengkap tanpa pertunjukan Tarian Sanghyang Manik Geni. Melalui tari sakral Sanghyang Manik Geni, masyarakat Desa Adat Canggu melakukan pemujaan kepada Tuhan Yang Maha Esa/Sang Hyang Widhi Wasa.

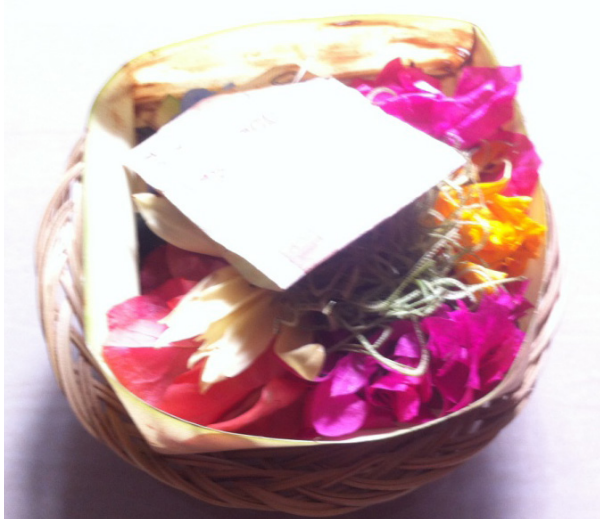

Gambar 2. Canang Penguleman

(Dok: AA Ngr Oka 2015)

Dalam menarikan Sanghyang Manik Geni, sang penari memakai pakaian adat yang umumnya digunakan oleh seorang sutri, berupa kain putih, baju putih, dan selendang yang berwarna putih (Lihat Gambar 1). Tarian Sanghyang Manik Geni ini juga menggunakan sesenden yang berisi bara api (Teteken) yang ditaruh di atas kepala sang penari sambil mengisap beberapa batang rokok. Sebelum pergi ke pura melakukan ngayah, ia diberikan canang penguleman sebagai simbol bahwa dirinya diberikan undangan ke pura untuk ngayah. Canang penguleman tersebut diaturkan ke pemerajan seorang sutri untuk meminta izin secara niskala, bahwa dirinya akan pergi ke pura tersebut untuk ngayah (Gambar 2).

Tarian Sanghyang Manik Geni menggunakan sarana berupa bara api (teteken). Teteken adalah sebuah sesenden yang berisi bara api yang digunakan oleh sang penari sebagai unsur kekuatan alam sebagai salah satu unsur dari Panca Maha Bhuta. Api juga berfungsi sebagai sarana untuk penyaksian upacara sekala maupun niskala. Kebesaran dari Ida Sang Hyang Widhi Wasa di tunjukan oleh seorang sutri yang menaruh teteken tersebut di atas kepalanya tanpa merasa sakit/panas karena penari tersebut sudah mengalami kerawuhan. Tetekan dapat dilihat pada gambar 2 .

Selain pakain serba putih, canang dan teteken, pementasan Tari Sanghyang Manik Geni diiringi dengan gambelan atau gong gede, dengan jumlah penabuhnya 30 orang. Gong ini terdiri dari: kendang dua buah, gangsa empat buah, ugal satu buah, kantil empat buah, jublag dua buah, jegog dua buah, gong lanang wadon, klentong, kempluk satu buah, cengceng penyu satu buah, dan delapan buah cengceng besar. Keberadaan perangkat gambelan ini akan saling mempengaruhi antara satu dengan yang lainnya, suara tabuh yang ditimbulkan akan terdengar berbeda apabila salah satu perangkat tidak ada.

Para pemangku dan sutri yang berada di pura tersebut sudah bersiap pada saat akan dilaksanakannya upacara $p i-$ 
odalan. pemangku memasuki puncak kerawuhan sebagai symbol dari kebesaran Ida Sanghyang Widhi Wasa yang turun ke dunia menyaksikan upacara yang di persembahkan, begitu juga seorang sutri yang menarikan tari Sanghyang Manik Geni sudah memasuki kerawuhan, dan meminta para penabuh untuk memulai gambelan yang dinamai tut-tut candung untuk mengiringi tarian Sanghyang Manik Geni ini.

Gerakan tarian Sanghyang Manik Geni ini sangat sederhana. Tidak terdapat pakem-pakem khusus tarian sakral yang dipentaskan di Pura Serayu, desa Canggu ini. Sang penari dalam kondisi trance (kerauhan) bergerak secara alami. Ia dimasuki roh suci dari bhatara-bhatari kahyangan, yang disambut baik untuk menyaksikan upacara yang sedang berlangsung. Setelah beberapa menit menari dalam kondisi kerawuhan sang penari diberikan tirta dan tetabuhan agar sang penari mengakhiri tarian tersebut dan kembali sadar, begitu juga dengan suara gambelan, seorang penabuh yang melihat sang penari sudah mulai sadar juga ikut mengakhiri suara gambelannya.

Sesuai prinsip teori estetika, keindahan yang ditunjukan oleh penari Sanghyang Manik Geni nampak dalam gerakannya yang halus sambil menggunakan sesenden yang berisi bara api (teteken) yang ditaruh di atas kepalanya tanpa merasa panas dan sambil mengisap beberapa batang rokok. Hal tersebut dikarenakan seorang penari sudah memasuki kerawuhan yang dilakukan dengan proses menghirup asap kemenyan, konsentrasi yang penuh, dan mendengar gambelan, semua proses tersebut didasari oleh kepercayaan atau religi.

\section{Fungsi Tari Sanghyang Manik Geni}

Kesenian dalam perspektif Hindu di Bali mempunyai kedudukan yang sangat mendasar karena tidak dapat dipisahkan dari religius masyarakat Hindu di Bali. Upacara di pura-pura atau tempat suci tidak lepas dari kesenian seperti seni suara, tari, rupa, dan sastra. Candi-candi dan pura-pura dibangun sedemikian rupa sebagai ungkapan rasa estetika, etika, dan sikap religius dari para penganut Hindu di Bali. Pregina atau penari dalam semangat ngayah atau bekerja tanpa pamerih mempersembahkan kesenian tersebut sebagai wujud bakti kehadapan Ida Sang Hyang Widhi Wasa atau Tuhan Yang Maha Esa. Di dalamnya ada rasa bakti dan pengabdian sebagai wujud kerinduan bertemu dengan sumber seni itu karena sesungguhnya tiap-tiap insan di dunia ini adalah percikan seni.

\section{Fungsi Ritual}

Upacara religi dalam kebudayaan dan masyarakat sederhana dan primitif dianggap sebagai usaha untuk mencari asas-asas religi kuno dan usaha memecahkan masalah asal mula religi. Secara umum, terdapat tiga golongan teori religi, yaitu (1) teori-teori yang dalam pendekatannya berorientasi kepada keyakinan religi atau isi ajaran religi, (2) teori-teori yang dalam pendekatannya berorientasi kepada

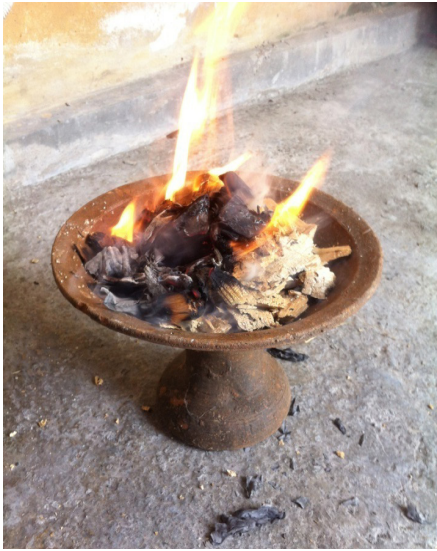

Gambar 3. Sesenden yang berisi bara api (teteken) (Dok: AA Ngr Oka 2015)

sikap para penganut religi yang bersangkutan terhadap alam gaib, dan (3) teori-teori yang dalam pendekatannya berorientasi kepada ritus dan upacara religi. Selanjutnya, Fraser membagi lima unsur religi yang saling berkaitan antara satu dengan yang lainnya yaitu : 1) emosi keagamaan, 2) sistem kepercayaan, 3) umat penganut agama, 4) peralatan upacara, dan 5) sistem upacara. Kelima unsur tersebut merupakan satu kesatuan yang bulat dan tidak dapat dipisahkan (Koentjaraningrat, 1985).

Tari Sanghyang Manik Geni merupakan salah satu tari wali, seperti halnya tari wali lainnya, tari ini memiliki fungsi yang sama yaitu sebagai pelengkap yadnya yang sedang diselenggarakan oleh yang bersangkutan, tanpa pementasan tari ini yadnya dianggap kurang lengkap. Dalam suatu upacara, tari Sanghyang merupakan simbol widyadari sesuhunan yang turun ke dunia pada saat piodalan (odalan) di pura bersangkutan. Pada suatu upacara biasanya tari Sanghyang yang dipentaskan adalah tari rejang dewa yang ditarikan oleh beberapa sutri sebagai simbol widyadari.

\section{Fungsi Sosial-Ekologis}

Dalam teori fungsional-struktural (R. Brown) dinyatakan bahwa sistem budaya dapat dipandang memiliki kebutuhan sosial, budaya itu muncul karena adanya tuntutan tertentu baik lingkungan maupun pendukungnya. Tuntutan itu menyebabkan budaya semakin tumbuh dan berfungsi menurut strukturnya. Dalam kehidupan manusia terdapat hubungan sosial yang khusus dan membentuk suatu keseluruhan yang padu seperti halnya struktur organik. Karena itu dalam analisis fungsi harus menghubungkan institusi sosial dan kebutuhan masyarakat. Istilah fungsi dan struktur sosial yang dilihat dalam masyarakat manusia bukan semata-mata keadaan individu, tetapi dilihat dari hasil struktur sosial yang menyatukan mereka (Endraswara, 2003:103).

Rasa solidaritas dan kebersamaan menjadi semakin kuat dengan adanya kegiatan ritual bersama dalam sebuah upacara. Kohesi sosial masyarakat adat desa Canggu menja- 
di semakin kuat dengan adanya upacara dewa nyadnya di Pura Serayu tersebut. Di sini, pementasan tari Sanghyang Manik Geni memiliki fungsi sosial, yakni menguatkan sentiment kebersamaan dan solidaritas umat Hindu setempat. Selain sebagai pelengkap yadnya dan menguatkan kohesi sosial, upaya pementasan tari Sanghyang Manik Geni juga berfungsi untuk penolak bala dan hama penyakit serta menjaga keharmonisan kehidupan manusia selaku buana alit dengan alam semesta sebagai buana agung. Mayoritas masyarakat Desa Canggu yang masih menjalani kehidupan sebagai petani menghendaki agar hasil tanaman pertanian mereka melimpah, terhindar dari serangan penyakit hama, kehidupan mereka dijauhkan dari marabahaya, serta lingkungan alam tempat hidup mereka tetap seimbang dan lestari. Secara langsung maupun tidak langsung, pementasan tari Sanghyang Manik Geni memiliki fungsi ekologis, yakni ikut memperkuat kesadaran masyarakat setempat dalam menjaga kelestarian lingkungan hidup. Hal ini sesuai temuan peneliti sebelumnya bahwa upacara tumpeh uduh dalam masyarakat Hindu di desa Canggu sebagai wahana pelestarian lingkungan hidup (Karmini, 2019).

Tradisi pementasan tari Sanghyang Manik Geni dalam upacara dewa yadnya yang menopang upaya pelestarian lingkungan hidup ini sesuai dengan prinsip pembangunan pariwisata berkelanjutan. Strategis pembangunan pariwisata berkelanjutan dewasa ini harus berpedoman pada prinsip-prinsip pembangunan berkelanjutan, yakni pembangunan yang menjamin: (a) kelangsungan ekologis, (b) kelangsungan sosial-budaya, dan (c) kelangsungan ekonomi (Anom, 2010: 5).

\section{Nilai-Nilai Pendidikan Tari Sanghyang Manik Geni}

Kata nilai berarti sifat-sifat atau hal-hal yang penting atau berguna bagi kemanusiaan (Poerwadarminta, 1985:677). Nilai merupakan sesuatu yang berharga dan berguna bagi manusia, dapat dijadikan pedoman menuju kehidupan yang lebih baik. Tari Sanghyang Manik Geni memiliki nilai estetik, nilai sosial dan nilai edukatif.

\section{a.Nilai Estetika}

Nilai adalah pilihan-pilihan ideal yang telah diterima dan diakui serta mengandung komitmen masyarakat. Dalam dimensi sosial, nilai adalah norma standar prilaku atau prinsip-prinsip yang mengarahkan atau membimbing prilaku seseorang. Estetika merupakan cabang filsafat yang membahas tentang seni dan keindahan. Obyek dari estetika adalah pengalaman akan keindahan. Dalam estetika yang dicariadalah hakekat dari keindahan, bentuk-bentuk pengalaman keindahan (seperti keindahan jasmani dan keindahan rohani, keindahan alam dan keindahan seni), diselidiki emosi-emosi manusia sebagai reaksi terhadap yang indah, yang agung,yang tragis, yang bagus, yang mengharukan, dan sebagainya (Surajiyo, 160). Nilai estetika yang terdapat dalam Tari Sanghyang Manik Geni dapat dilihat dalam gerakannya yang halus mencirikan kesenangan sang widyadari yang turun kedunia menyaksikan upacara, selain itu teteken yang di taruh di atas kepala sang penari sambil mengisap beberapa batang rokok, menunjukan rasa keindahan dan keunikan dalam tarian tersebut. Tari Sanghyang Manik Geni pada upacara piodalan di Pura serayu Desa Adat Canggu, Kecamatan Kuta Utara Kabupaten Badung.

\section{b.Nilai Sosial-Religius}

Nilai sosial mempunyai pengertian suatu kebaikan dan nilai-nilai kebaikan yang berlaku secara sosial dan harus direalisasikan dalam kehidupan manusia khususnya umat Hindu. Dalam kaitan ini, seorang penari tari Sanghyang manic Geni (sutra) menyadari bahwa dirinya diberikan tugas untuk ngayah. Nilai sosial-religius yang terkandung dalam tarian Sanghyang Manik Geni tercermin dalam ketulusan sang penari (sutri) yang rela mengorbankan waktunya untuk ngayah tanpa meminta imbalan. Hal tersebut dikarenakan adanya jiwa sosial yang dimiliki pada seorang sutri. Dengan melakukan ngayah seorang sutri sudah menunjukan rasa bakti kepada Ida Sanghyang Widhi Wasa atau Tuhan Yang Maha Esa.

Pementasan tari Sanghyang Manik Geni merupakan upaya penegakan filosofi Tri Hita Karana. Menurut Mantra (1996), Tri Hita Karana adalah keseimbangan antara manusia dengan sesamanya (Pawongan), manusia dengan lingkungannya (palemahan) dan hubungan manusia dengan TuhanNya (parahyangan). Bilamana ditinjau dari segi filosofi Tri Hita Karana, persembahan tari Sanghyang Manik Geni dalam proses upcara dewa yadna di Pura Serayu, Desa Canggu merupakan ekspresi dari upaya manusia dalam menjaga keharmonisan dengan Tuhan (parahyangan), sekaligus sebagai upaya menjaga keseimbangan dengan lingkungan alam (palemahan) dan menjaga hubungan harmonis antar manusia (pawongan). Upaya penegakan prinsip Tri Hita Karana (THK) akan berarti bagi pembangunan pariwisata Bali yang berkelanjutan dalam memelihara mutu sumber daya alam dan budaya dan meningkatnya kesejahteraan masyarakat lokal (Ardika, 2007).

\section{c.Nilai Pendidikan}

Disamping mengandung nilai estetis yang tinggi, nilai sosial religius, persembahan tari Sanghyang Manik Geni di Pura Serayu, Desa Canggu juga mengandung nilai pendidikan. Pertama, pendidikan akan rasa bhakti penuh keihklasan dalam berbhakti kepada Hyang widi wasa. Pendidikan adalah usaha sadar dan terencana untuk mewujudkan suasana belajar dan proses pembelajaran agar peserta didik secara aktif mengembangkan potensi dirinya untuk memiliki 5 kekuatan spiritual keagamaan, pengendalian diri, kepribadian, kecerdasan, akhlak mulia, serta keterampilan yang diperlukan dirinya, masyarakat, bangsa dan negara (Pasal 1, UU Pendikan No 20/2003). Mendidik, mengajar, membimbing kepribadian seseorang dalam mempelajari seni tari adalah hal yang sangat penting, karena kesenian, khususnya seni tari selalu diperlukan untuk mengiringi ke- 
giatan upacara umat Hindu Bali, termasuk seni tari Sanghyang Manik Geni pada upacara piodalan di Pura Serayu Desa Adat Canggu, Kabupaten Badung.

Secara umum, pementasan tari Sanghyang Manik Geni merupakan wahana pendidikan agama Hindu dari generasi terdahulu ke generasi berikutnya. Pementasan tari sakral Sanghyang manik Geni yang dilakukan oleh generasi tua seolah menunjukkan contoh atau keteladanan dari generasi tua kepada generasi muda untuk mempertahankan dan mengelola tradisi agama Hindu Bali yang dilaksanakan oleh masyarakat pendukung Pura Serayu, Desa Canggu. Sang penari (seorang sutra) dengan penuh keihklasan dan kesadaran rela mengorbankan waktunya untuk bisa tedun (datang) ketika ada piodalan di pura Serayu, walaupun tanpa imbalan. Hal itu yang dilakukan oleh seorang sutri sebagai perwujudan rastiti bakti kepada Ida Sang Hyang Widhi Wasa. Wujud rastiti bakti kepada Ida Sanghyang Widhi Wasa juga dapat dilihat dari Tarian Sanghyang Manik Geni yang tidak sembarangan, melainkan menunjukan sifat kesakralan.

Kedua, pendidikan tentang pentingnya upaya sosialisasi dan enkulturasi (pembudayaan) nilai-nilai ajaran agama Hindu kepada generasi penerus. Melalui persembahan tari Sanghyang Manic Geni, para pemuka agama (generasi tua) Hindu di desa Canggu secara langsung maupun tidak langsung memberikan pengajaran tentang makna upaya dewa yadnya sebagai ekspresi rasa bhakti kepada Hyang Widi Wasa. Sesuai dengan kata Anthony Gidden (1992:76), proses sosialisasi nilai-nilai ajaran agama kepada generasi penerus ini amat penting untuk kesinambungan tradisi. Menurut para pemuka agama desa Canggu, upaya sosialisasi dan enkulturasi nilai-nilai ajaran agama Hindu kepada generasi penerus ini dianggap penting agar anak-anak mereka memiliki kesadaran religius dan memiliki karakater kepribadian sebagai orang Bali yang memiliki seni-budaya dan tradisi tersendiri. Upaya membangun karakter kepribadian merupakan proses yang berlangsung seumur hidup. Perkembangan karakter pada setiap individu dipengaruhi oleh faktor bawaan (natur) dan paktor lingkungan (nurture). Menurut para ahli psikologi perkembangan, setiap manusia memiliki potensi bawaan yang akan termanisfestasi setelah dia dilahirkan, termasuk potensi yang terkait dengan karakter atau nilai-nilai kebajikan (Latifah, 2008: 49). Sejalan dengan hal itu Confusius menyatakan bahwa manusia pada dasarnya memiliki potensi mencintai kebajikan, namun bila potensi ini tidak diikuti dengan pendidikan dan sosialisasi setelah manusia dilahirkan, maka manusia akan dapat berubah menjadi binatang, bahkan lebih buruk lagi (Megawangi, 2003: 33).

\section{SIMPULAN}

Pementasan tari Sanghyang Manik Geni yang diiringi oleh gamelan gong gede merupakan tari wali, dipentaskan di setiap piodalan di bagian utama mandala pura Serayu desa Canggu oleh seorang penari (sutri/pemangku). Tari sakral yang dipentaskan setiap buda manis dukut sebagai bagian dari prosesi upacara dewa yadnya dalam menunjukan rasa bakti kepada Ida Sang Hyang Widhi Wasa. Penari Sanghyang Manik Geni memakai berupa kain putih, baju putih, dan selendang yang berwarna putih, serta memakai alat upkara berupa canang dan bara api (teteken). Tari Sanghyang Manik Geni memiliki beberapa fungsi: (a) fungsi ritual sebagai bagian dari upcara dewa yadnya, (b) fungsi sosial, yakni menguatkan rasa kebersamaan dan solidaritas masyarakat adar Desa Canggu, serta (c) fungsi ekologis yakni ikut memperkuat kesadaran masyarakat setempat dalam menjaga keseimbangan dan kelestarian lingkungan hidup.

Disamping mengandung nilai estetis yang tinggi, nilai sosial religius, persembahan tari Sanghyang Manik Geni di Pura Serayu, Desa Canggu juga mengandung nilai pendidikan. Pertama, pendidikan akan rasa bhakti penuh keihklasan kepada Hyang Widi Wasa. Kedua, pendidikan tentang pentingnya menjaga keseimbangan dan pelestarian lingkungan hidup. Ketiga, pendidikan tentang pentingnya upaya sosialisasi dan enkulturasi (pembudayaan) nilainilai ajaran agama Hindu kepada genersi penerus.

\section{DAFTAR RUJUKAN}

Anom, I Putu. 2010. "Pembangunan Pariwisata Berkelanjutan", dalam Pariwisata

Ardika, I Wayan. 2007. Pusaka Budaya dan Pariwisata. Denpasar: Pustaka Larasan.

Bandem, I Made. 1983. Ensiklopedi Tari Bali. Denpasar: ASTI Denpasar.

Cudamani, 1987. Pengantar Agama Hindu .Jakarta: Yayasan Wisma Karma

Dibia, I Wayan. 1979. Sinopsis Tari Bali.Denpasar: Sanggar Tari Bali Waturenggong.

Endraswara, Suwardi. 2003. Metodologi Penelitian Sastra. Yogyakarta: Pustaka

Giddens, Anthony. 1992. Sociology. Cambridge: Polity Press.

Koentjaraningrat, 1985, Ritus Peralihan di Indonesia, Jakarta: P.N. Balai Pustaka.

Latifah, Melly. 2008. Peranan Keluarga dalam Pendidikan Karakter Anak. (Online). Tersedia: http://www.tumbuh-kembang. Diakses 03 Maret 2017.

Mantra, Ida Bagus. 1996. Landasan Kebudayaan Bali. Denpasar: Yayasan Dharma Sastra. 
Megawangi, Ratna. 2003. Pendidikan Karakter untuk Membangun Masyarakat Madani. IPPK Indonesia Heritage Foundation.

Peraturan Daerah Provinsi Bali. Nomor 2 Tahun 2012. Tentang. Kepariwisataan Budaya Bali

Poerwadarminta. 1985, Kamus Besar Bahasa Indonesia, Jakarta: Balai Pustaka, Karmini, 2018

Karmini, Ni Wayan, dkk. 2019. Tumpek Uduh Ceremony As An Education Medium In The Preservation Of Natural Environtment In Bali: Case Study In Canggu Village, Kuta Utara District,Badung Regency, Bali; The Asian International Journal of Life Sciences, Asia Life Sciences 28 (1): $1-29$.

Suradnya, I Made. 2006. Analisis Faktor-Faktor Daya Tarik Wisata Bali Dan Implikasinya Terhadap Perencanaan Pariwisata Daerah Bali. Denpasar: Sekolah Tinggi Pariwisata Bali.

Surajiyo. 2015. Keindahan Seni Dalam Perspektif Filsafat, Jurnal Desain, vol 3, No. 2, Mei 2015, hal 160.

Undang-undang Republik Indonesia No 9 Tahun 1990 Tentang Kepariwisataan.

Undang-Undang Nomor 20 Tahun 2003 Tentang Sistem Pendidikan Nasional 